\author{
Abstracta Iranica \\ Abstracta Iranica Revue bibliographique pour le domaine irano-aryen \\ Volume 32-33 | 2013 \\ Comptes rendus des publications de 2009-2010
}

\title{
Jean Perrot (dir.). Le palais de Darius à Suse. Une résidence royale sur la route de Persépolis à Babylone
}

\section{Astrid Nunn}

\section{OpenEdition}

\section{Journals}

Édition électronique

URL : http://journals.openedition.org/abstractairanica/40387

DOI : 10.4000/abstractairanica.40387

ISSN : 1961-960X

Éditeur :

CNRS (UMR 7528 Mondes iraniens et indiens), Éditions de l'IFRI

\section{Édition imprimée}

Date de publication : 1 décembre 2013

ISSN : 0240-8910

\section{Référence électronique}

Astrid Nunn, « Jean Perrot (dir.). Le palais de Darius à Suse. Une résidence royale sur la route de Persépolis à Babylone », Abstracta Iranica [En ligne], Volume 32-33 | 2013, document 105, mis en ligne le 01 juillet 2016, consulté le 10 décembre 2020. URL : http://journals.openedition.org/ abstractairanica/40387 ; DOI : https://doi.org/10.4000/abstractairanica.40387

Ce document a été généré automatiquement le 10 décembre 2020.

Tous droits réservés 


\title{
Jean Perrot (dir.). Le palais de Darius à Suse. Une résidence royale sur la route de Persépolis à Babylone
}

\author{
Astrid Nunn
}

\section{RÉFÉRENCE}

Jean Perrot (dir.). Le palais de Darius à Suse. Une résidence royale sur la route de Persépolis à Babylone. Paris, Presses de l'Université Paris-Sorbonne, 2010, 520 p., nombreuses illustrations en couleur.

1 «Ce livre rassemble et présente les connaissances actuelles concernant Suse au temps des Grands rois perses achéménides à travers les constructions de Darius et de ses successeurs ", voilà le but de ce superbe livre auquel ont participé de nombreux spécialistes de l'époque achéménide. Même si le souvenir de Suse ne s'était jamais perdu grâce aux récits bibliques, c'est à l'archéologie que l'on doit les informations dont nous disposons aujourd'hui.

D'emblée, dès avant le premier chapitre historique sur «Suse et l'Élam dans l'empire achéménide » (P. Briant) le lecteur est confronté avec des reconstructions virtuelles du Palais, expliquées en détail dans le chapitre sur la reconstitution. F. Vallat évoque la personnalité de Darius le Grand et N. Chevalier l'histoire des découvreurs de Suse depuis W. K. Loftus en 1850. Les chapitres suivants esquissent un historique des fouilles (J. Perrot), leurs techniques (A. Hesse), les données archéologiques (fondations, construction et édifices, D. Ladiray) puis le problème de la restauration et de la reconstitution (J. Perrot). J. Yoyotte s'attache à la seule grande statue achéménide jamais trouvée qu'est celle de Darius, F. Vallat passe en revue les inscriptions achéménides de Suse et retraduit l'inscription de Darius à Béhistoun (DB). Les chapitres 
suivants sont de nouveau consacrés au matériel archéologique que sont les briques ornementales et les objets mobiliers en faïence (A. Caubet et N. Daucé), l'art mobilier (P. Amiet, C. Frank), puis aux techniques de construction et à la décoration des autres travaux de Darius et de ses successeurs que sont les palais « du Donjon » et du Chaour ainsi que les trésors royaux (R. Boucharlat). Enfin, l'architecture de Suse est replacée dans un contexte plus global perse (R. Boucharlat) et proche-oriental (H. Gasche) qui pour la première fois examine en détail la construction achéménide de la Südburg à Babylone. Cet ouvrage termine avec des considérations plus conceptuelles sur les principes de l'architecture susienne, la beauté et les croyances au temps de Darius (J. Perrot) ainsi que sur les Perses et le monothéisme juif (J. Soler). De nombreux plans, des encarts et d'innombrables photos d'objets non ou peu connus, tels certaines briques vernissées, des petits objets, de la vaisselle, des ivoires font de cette publication un ouvrage fondamental qui ne pourra être dépassé que par de nouvelles fouilles sur place.

\section{AUTEURS}

\section{ASTRID NUNN}

Université de Munich 